\title{
Oecanthus rohiniae sp. nov. (Gryllidae: Oecanthinae): A new chirping tree cricket of the rileyi species group from Mexico
}

\author{
Nancy Collins', Isabel Margarita Coronado-González², Aurora Y. Rocha-Sánchez, Bruno Govaerts², \\ Wilbur Hershberger ${ }^{4}$
}

\author{
1 Waterford, Racine County, Wisconsin, USA. \\ 2 Fraccionamiento Vista Real, Corregidora, Querétaro, Mexico. \\ 3 Hospital Regional de Alta Especialidad de Ciudad Victoria "Bicentenario 2010", Victoria, Tamaulipas, Mexico. \\ 4 Hedgesville, Berkeley County, West Virginia, USA. \\ Corresponding author: Nancy Collins (ycnancy2k@hotmail.com) \\ Academic editor: Klaus-Gerhard Heller | Received 10 January 2020 | Accepted 23 June 2020 | Published 18 February 2021 \\ http://zoobank.org/453DAF66-5CC1-4CC9-870E-2EDD98BFDE52
}

Citation: Collins N, Coronado-González IM, Rocha-Sánchez AY, Govaerts B, Hershberger W (2021) Oecanthus rohiniae sp. nov. (Gryllidae: Oecanthinae): A new chirping tree cricket of the rileyi species group from Mexico. Journal of Orthoptera Research 30(1): 7-16. https://doi.org/10.3897/jor.30.50039

\begin{abstract}
A new species of Oecanthus is described from Mexico. Oecanthus rohiniae sp. nov. occurs in central Mexico in the understory of tropical deciduous forest and is currently known only from Mexico. This new species has the coloring, antennal markings, slightly widened tegmina, and calling song that are found in the rileyi species group. Although morphologically very similar to Oecanthus fultoni, the shapes of the distal hooks on the male copulatory blades differ between the two species. There are also differences in the song pulse patterns and chirp rate response to temperature. This new species has been given the common name Cri-Cri tree cricket. Video and song recordings are available online.
\end{abstract}

\section{Keywords}

bioacoustic, biodiversity, Querétaro, tropical deciduous forest

\section{Introduction}

According to the Orthoptera Species File (Cigliano et al. 2020), the subfamily Oecanthinae Blanchard, 1845, is represented by nine genera: Oecanthodes Toms \& Otte, 1988; Oecanthus Serville, 1831; Viphyus Otte, 1988; Leptogryllus Perkins, 1899; Prognathogryllus Brunner von Wattenwyl, 1895; Thaumatogryllus Perkins, 1899; Neoxabea Kirby, 1906; Xabea Walker, 1869; and Paraphasius Chopard, 1927. Two of these genera occur in Mexico-Oecanthus and Neoxabea. Twenty of the species of Oecanthus in North Ameri$\mathrm{ca}$, Central America, and the Caribbean are divided into four main species groups: nigricornis, niveus, varicornis, and rileyi (Walker 1962, 1963, Walker and Collins 2010, Singing Insects of North America 2020b). These groups can be distinguished by characteristics including song type (chirping vs trilling and continuous vs intermittent); song pulse or chirp rate at given temperatures; regular vs irregular pattern of pulses or chirps; coloration of the antennae, head, pronotum, and abdomen; antennal markings on the pedicel and scape; and tegminal width (Walker 1962, 1963, Walker and
Collins 2010). Four species in the rileyi species group are currently known to occur in North America, Central America and the Caribbean (Walker 1967, Collins et al. 2014): O. alexanderi Walker, 2010 (Walker and Collins 2010); O. allardi Walker \& Gurney, 1960; O. fultoni Walker, 1962; and O. rileyi Baker, 1905.

In 1960, Walker and Gurney published the description of O. allardi and included details of ten specimens of snowy tree cricket from Tamaulipas and Michoacán, Mexico. In 1965, Richard D. Alexander traveled throughout Mexico and recorded Orthoptera and other singing animals. Notes from his recordings include six tapes that mention 'fultoni' with adjectives such as slow, fast, and grouped or not grouped (Suppl. material 1: historical recordings). No further investigations of chirping tree crickets are known to have occurred in Mexico until the description of $O$. mhatreae Collins \& Coronado, 2019 (Collins et al. 2019).

In 2019, a photograph accompanied by a sound recording (iNaturalist 2020) posted on iNaturalist.org from the central Mexican state of Querétaro led to the investigation of a new species of Oecanthus tree cricket. The chirping song pattern, widened tegmina, and orange area on the head are characters found in the rileyi species group. Although other photos from Mexico of tree crickets resembling the rileyi species group have been posted on iNaturalist, none had previously been accompanied by recordings of their songs. After reviewing all material, it was discovered that the samples did not correspond to any of the described taxa. This paper describes a new species of Oecanthus collected in Querétaro.

\section{Material and methods}

Specimens._Adults and nymphs of Oecanthus were collected from a private property and immediate surrounding areas of Fraccionamiento Vista Real, Corregidora, State of Querétaro, Mexico. This locality is near Parque Nacional El Cimatario, on the southern slope of Cerro de Cimatario. Specimens were initially located by the song of the males and collected manually. Females and 
nymphs were found in the same area. Tree crickets were brought indoors in plastic containers $(15 \times 15 \times 20 \mathrm{~cm})$ with holes on the side for ventilation. The males and females were kept alive and separated to be recorded and then preserved in $70 \%$ ethyl alcohol for morphological studies. Photographs and measurements of diagnostic characters were made with a Jiusion Digital Microscope Model USB, magnification $40 \times$ to $1000 \times$ (ovipositor, cerci, and metanotal gland), MOTIC-SWZ168739 stereo-microscope at 40× and equipped with a $10 \mathrm{mp}$ digital camera (internal genitalia). Characters considered for description are as follows: body length, head colors, antennal colors and markings, pronotum in dorsal view, tegmina length and width, stridulatory file, metanotal gland, cerci, subgenital plate, and internal genitalia (copulatory blades). Additional characters for females included the ovipositor, subgenital plate and cerci. The following measurements were made: body length-from the tip of the labrum to the apex of the subgenital plate; pronotum length (from anterior to posterior margin along midline); pronotum width (at the widest distal portion in dorsal view); tegmina length (from the thorax joining point to distal end of tegmina along midline); tegminal width (measured at the widest section of tegmina at rest); hind femur length; and cerci length. The females' ovipositors were measured from the base (closest portion to the abdomen) to the distal tip. Copulatory blades (Fulton 1915) project from the male genitalia complex and are situated just above the subgenital plate. These genitalia structures have also been referred to as pseudepiphallus (Chopard 1961, 1969), lophi medians [middle lobes] (Desutter 1987), or main lobe of pseudepiphallus (Zefa et al. 2012). The genitalia of Mexican specimens were treated with an aqueous solution of 10\% potassium hydroxide (Rocha-Sánchez et al. 2018, Barrientos-Lozano and Rocha-Sanchez 2013). No chemicals were used on the O. fultoni specimen from the USA. Genus determination was made with keys from Walker (1967) and SINA (2020a) and review of taxa of Oecanthus in the Orthoptera Species File (Cigliano et al. 2020).

Calling song recording and analyses. - The male acoustic signal was recorded in the field and indoors using a Samsung Galaxy Tab S4 tablet model SM-T830, the app Grabadora Amazing, and a MixMart 8 GB, PCM, 1536 kbps digital voice recorder. Audio devices were tested for calibration by recording a reference time audio file with reference tones and comparing the results to the original file. The recording devices were kept at a distance of approximately $10 \mathrm{~cm}$ from the individual. Analyses of song recordings were made with the Raven Pro 1.6 program (Cornell Lab 2020). Audio waveforms were created using the programs Raven Lite 2.0 or Raven Pro 1.6 (Cornell Lab 2020). Grouped pulse patterns were determined by counting individual pulses within each chirp. A chirp consists of varying numbers of pulses, and each pulse corresponds to a single closure of the tegmina (Walker and Collins 2010). Ten randomly chosen chirp periods were measured for each recording to determine the chirps per minute rate for that sample. Additional recordings (Suppl. material 2: source recordings) from the Macaulay Library of Cornell Lab (2020) were used for the preparation of two graphs to compare chirps per minute vs temperature and carrier frequency vs temperature, with additional species in the rileyi group. Regression lines for the sampled O. rohiniae sp. nov. population were calculated in Microsoft Excel for Mac, Version 16.16.22 (200509) (2016). The slopes of the regression lines for O. rohiniae sp. nov. and $O$. fultoni were compared using the t-test procedure for paired samples from Wonnacott and Wonnacott (1977).
Climate.-Temperatures were measured using an ELMECO DTM2 digital thermocouple thermometer with a range of $-50^{\circ} \mathrm{C}$ to $1000^{\circ} \mathrm{C}$, with an accuracy of $0.1^{\circ} \mathrm{C}$. Ambient temperature and rainfall ranges [climatologia/temperaturas-y-lluvias/resumenesmensuales-de-temperaturas-y-lluvias] for 2018 and 2019 were taken from the National Water Commission weather website (NWC 2020). The light intensity was determined using a HIOKI model 3422 digital luxmeter with a range of 0 to $2000 \mathrm{Lx}$ (1Lx accuracy) and using data from the NWC website.

\section{Results}

\section{Oecanthus rohiniae Collins \& Coronado-González, sp. nov.} http://zoobank.org/EE607E6F-B950-4FDF-BCA0-742177F85FD4

Material examined. - Holotype: MEXICO • ô; Querétaro, Corregidora; 2130 MASL; 30.xi.2019; 2052'20"N, 100³8'80"W; I. Coronado leg.; deposited Universidad Nacional Autónoma de México (IB-UNAM). Paratypes: MEXICO $\bullet 2 \hat{\sigma}, 3$; ; same locality as holotype; 2 ô, 2 q deposited Tecnológico Nacional de México-Instituto Tecnológico de Ciudad Victoria (TecNM-ITCV); 1 qdeposited IB-UNAM.

Etymology. - Specific epithet in recognition of Rohini Balakrishnan whose research involves bioacoustics, animal behavior, ecology, and systematics. Her list of publications includes several that focus on or include tree crickets. The common name, Cri-Cri tree cricket, is named for Cri-Cri: El Grillito Cantor (Cri-Cri: The Little Singing Cricket), which was a character created by Francisco Gabilondo Soler, a Mexican composer and performer of children's songs. Additionally, the sound this tree cricket makes is written as "cri, cri..." in Spanish.

Holotype measurements. - Body length $13.0 \mathrm{~mm}$; tegminal length 13.0, tegminal width 6.0; pronotal length 2.0, distal pronotal width 2.0; hind femur length 7.0; cerci 5.0; stridulatory file length 1.8. Right tegminal stridulatory teeth total 46 .

Description. - Face pale; head with area of pale orange (Figs 4, 5). Scape translucent orange, pedicel translucent whitish (Fig. 6), and remainder of antennomeres translucent whitish. Ventral face of pedicel and scape each with one ovoid or rounded black mark on white field (Figs 3, 19). Eye color pale cream to violet. Palpi pale golden orange with whitish tips. Pronotum light green. Tympanal membrane on fore tibiae whitish. Wing color greenish. Ventral abdomen whitish with blotches of light green (Fig. 8). Tarsi, tibiae, and femora translucent pale green; some individuals with blackish thin line down inner femora. Cerci straight and translucent pale green.

Males.-Hind wings and cerci extend beyond distal edge of tegmina (Fig. 1). Tegmina with veins as in Fig. 2. Body length 13.0$13.5 \mathrm{~mm}$; tegminal length 13.0-13.5, tegminal width 5.8-6.0; pronotal length 2.0 , distal pronotal width 2.0-2.2; hind femur length 7.0-7.6; cerci 5.0; stridulatory file length 1.8-2.0. Right tegminal stridulatory teeth total 46-48. Metanotal gland with triangular opening, and bristles running horizontally across the top of the opening (Fig. 7). Subgenital plate tapers to a rounded tip (Fig. 8). Copulatory blades with rounded medial sides and a notch separating them slightly narrower than width of a blade. Each blade with a small hook at distal tip (Figs 9, 10). 

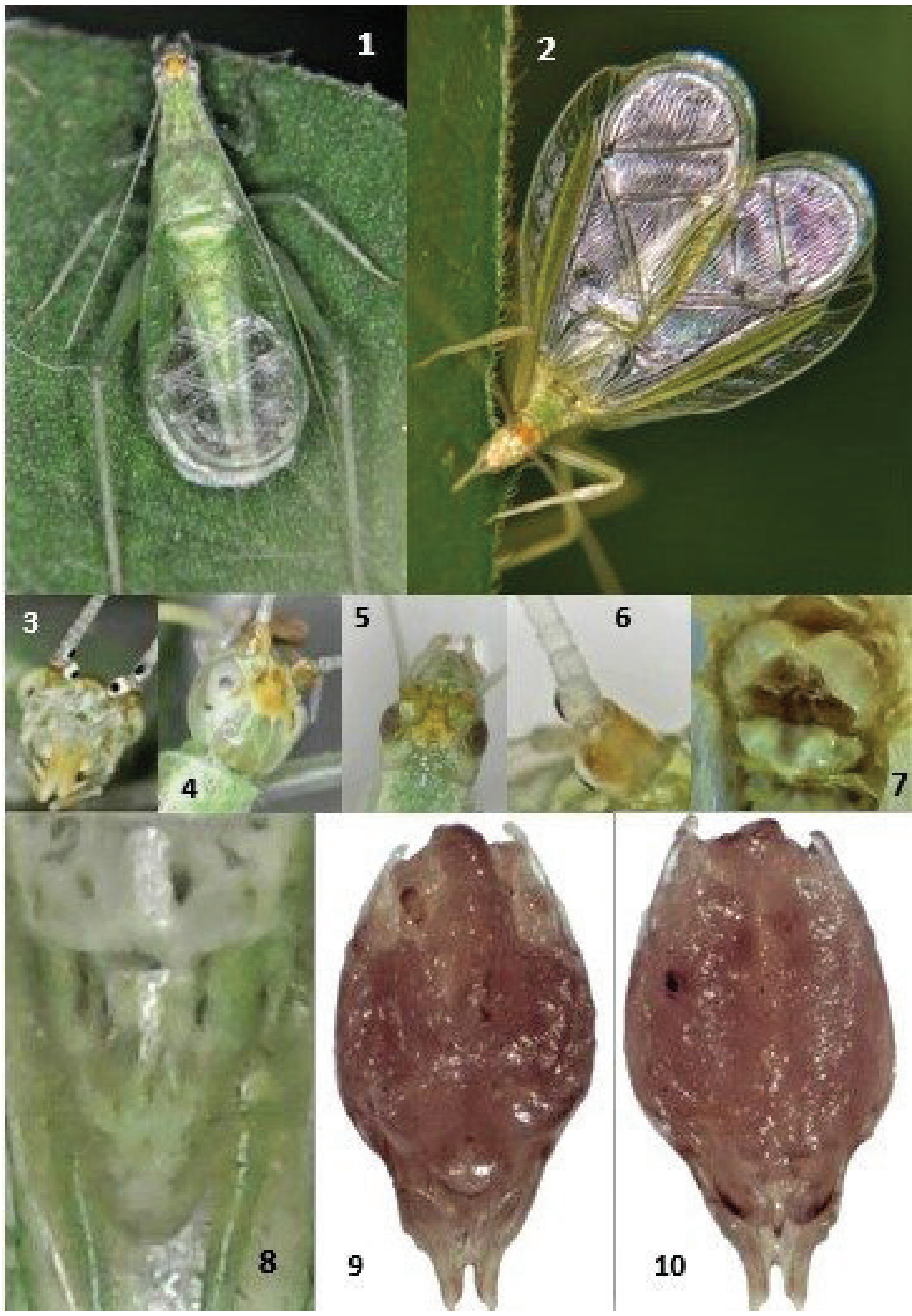

Figs 1-10. Oecanthus rohiniae sp. nov., male. 1. Habitus; 2. Singing male showing the tegmina in raised position; 3 . Head in frontal view showing the antennal marks; 4 . Rounded patch of color on head; 5 . Notched patch of color on head; 6 . Antennal base, lateral view; 7. Metanotal gland; 8 . Subgenital plate in ventral view; 9. Internal genitalia in ventral view; 10. Internal genitalia in dorsal view. 


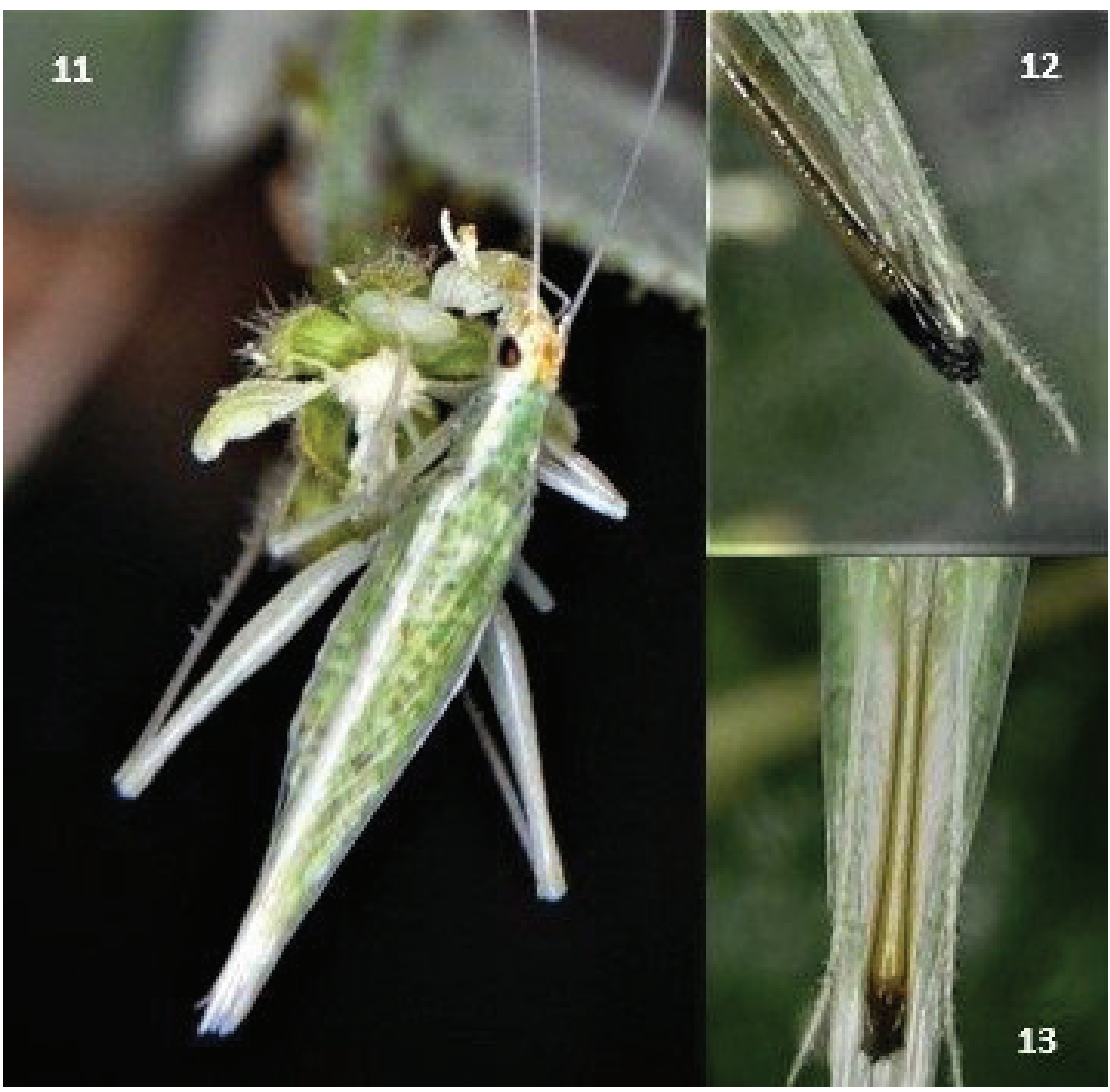

Figs 11-13. Oecanthus rohiniae sp. nov., female; 11. Habitus, female eating on Croton cilatoglandulifer Ort; 12. Cerci; 13. Ovipositor.

Morphological diagnosis. - Oecanthus rohiniae sp. nov. can be distinguished from O. rileyi by differences in antennal markings and from $O$. fultoni by differences in the distal hooks of the copulatory blades of the male genitalia. The antennal markings of O. rohiniae sp. nov. are centered and fairly equal in size (Figs 3, 20). The antennal marking on the pedicel of $O$. rileyi is positioned at the top of the segment, and is approximately one-half the size of the marking on the scape (Fig. 22). A drawing in Walker and Gurney (1960) of male genitalia shows that the distal ends of the copulatory blades of $O$. fultoni appear rounded with sharply pointed medially opposing hooks (Fig. 27). The distal ends of the copulatory blades of $O$. rohiniae sp. nov. are more blunted, and the tips of the hooks are less pointed (Fig. 23). A second drawing in Walker and Gurney (1960) shows an undetermined rileyi species group tree cricket from Tamaulipas, Mexico (Fig. 24) with hook position similar in appearance to O. rohiniae sp. nov. Photos of the lateral view of the blades of O. rohiniae sp. nov. (Fig. 25) and O. fultoni (Fig. 28) highlight the hook tip differences.

Female description. - (Figs 11-13) Latticed vein pattern on translucent greenish wings. Body length $11.5 \mathrm{~mm}$; pronotal length 2.0, distal pronotal width 2.0; hind femur length 7.0; cerci 4.5; ovipositor length 3.5. The length of the hindwings is variable. The tip of the ovipositor does not extend beyond the tips of the cerci. 


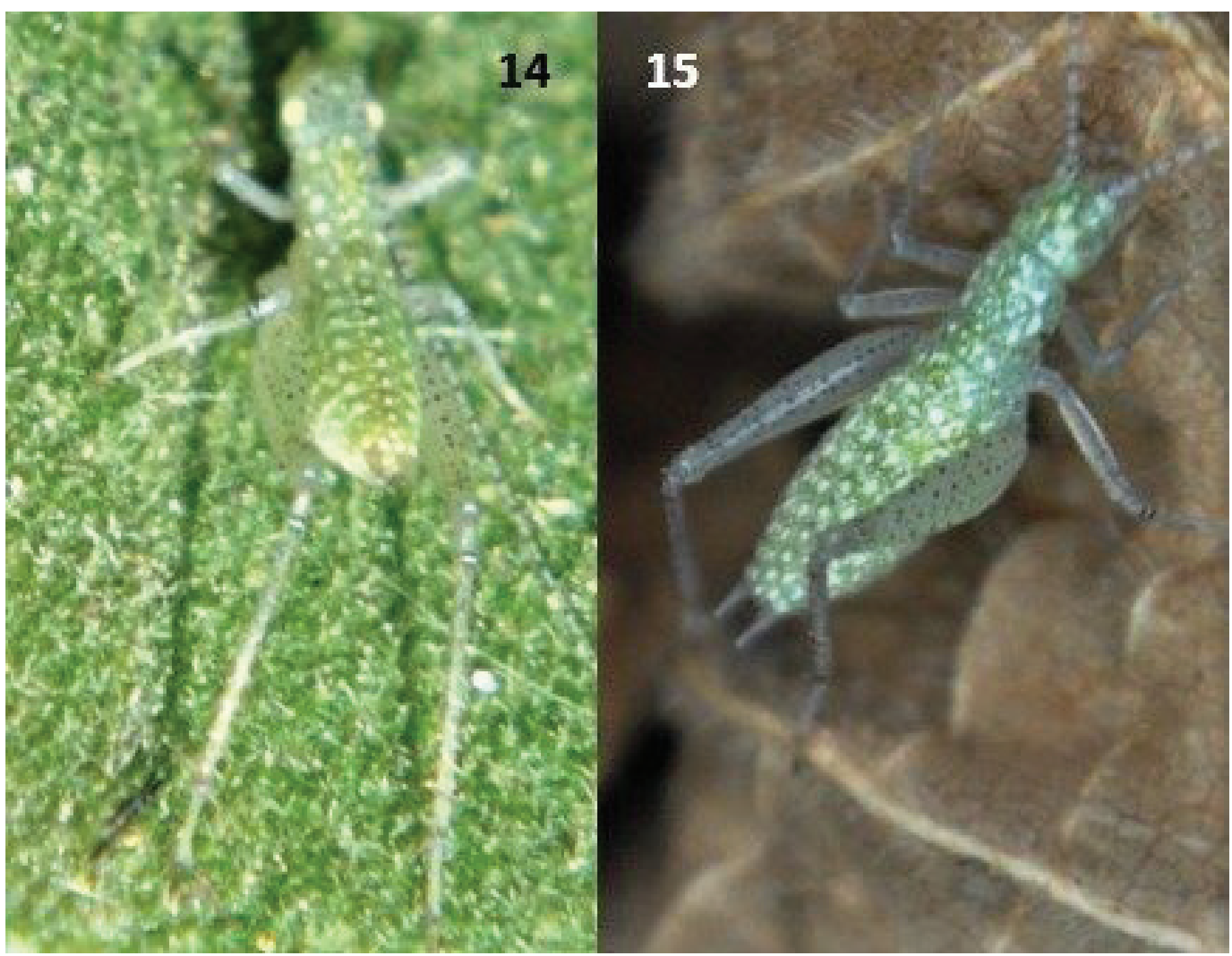

Figs 14, 15. Characters of $O$. rohiniae sp. nov. nymphs: Even rows of white rounded markings on the abdomen, black speckles on the hind femora, and black rings on the antennal filaments.

Nymphs.-(Figs 14, 15) Straight rows of white rounded marks on the abdomen, black speckles on the hind femora, and evenly spaced black rings on the antennal filaments. Nymphs of various instar stages, as well as adults, were encountered year round.

Distribution and habitat.-Cri-Cri tree crickets have only been collected in the type locality in the biogeographic province of the Trans-Mexican Volcanic Belt, in the State of Querétaro, located in the Central-South part of Mexico. The vegetation was categorized by dry shrubland with cacti (crassifolia), grassland (mattoral), reinvading natural vegetation on disturbed land (ruderal), and introduced plants. A total of 33 plant species were able to be identified in the type locality (Calderón de Rzedowski and Rzedowski 2001, Martínez-Sandoval 2017). Adults and nymphs of this new species of tree cricket were observed on 14 of these plant species and were witnessed feeding on eight plant species (native plants: Asclepias curassavica L., Croton cilatoglandulifer Ort., Justicia candicans (Nees) L.D., Lantana camara L., Lantana hirta Graham, Colubrina triflora Brogn Ex Sweet (also oviposition) and introduced plants: Calendula officinalis L., Cnidoscolus multilobus (Pax) I. M. Johnst, Ruta graveolens L., and Thunbergia alata Bojer
Ex Sims). An ovipositing female as well as nymphs were found on Colubrina triflora Brogn. Ex Sweet, a native plant. Nymphs were found on three native plants: Lantana hirta Graham, L. camara L, and C. cilatoglandulifer Ort.

Climate and light intensity.-National Weather Commission (NWC 2020) data for 2009-2019 showed the coldest months as December and January (lowest $4.0^{\circ} \mathrm{C}$ ) and the warmest months as April and May (highest $33.2^{\circ} \mathrm{C}$ ). The driest months tend to be November through March (lowest $0.0 \mathrm{~mm}$ ) and the wettest months tend to be June through September (highest $207.0 \mathrm{~mm}$ ). Males sing just before or after sunset with light measurements of $5 \mathrm{~W} / \mathrm{m}^{2}$ and temperatures as low as $11.0^{\circ} \mathrm{C}$.

Acoustics, chirp rates, frequencies, and slopes.-Recordings were made in the field and in captivity for O. rohiniae sp. nov. A sample recording can be heard in Suppl. material 3: WAV, and a stridulating male can be viewed in Suppl. material 4: MPG. After plotting the data of temperature vs chirps per minute and carrier frequency vs temperature, linear regression lines were calculated for $O$. rohiniae sp. nov., O. fultoni, and O. rileyi. The linear regression for tempera- 
ture vs chirps per minute of $O$. rohiniae sp. nov. was calculated to be $\mathrm{y}=7.0418 \times-5.3551$, and at $25.0^{\circ} \mathrm{C}$ the chirps per minute rate was 171 (Fig. 17). The linear regression for carrier frequency $(\mathrm{kHz})$ vs temperature (degrees celsius) of $O$. rohiniae sp. nov. was calculated to be $\mathrm{y}=0.0685 \mathrm{x}+0.09002$, and at $25.0^{\circ} \mathrm{C}$ the carrier frequency was $2.61 \mathrm{kHz}$ (Fig. 18). The chirps per minute rate vs temperature response of $O$. rohiniae sp. nov. is distinctly different from $O$. rileyi. The slopes of both $O$. rohiniae sp. nov. and $O$. fultoni were further examined using a t-test analysis. This analysis resulted in a t-value of $t(47)=3.08$ with a probability value of $p=0.0035$, clearly indicating that the slopes of the chirps per minute vs temperature response for both species are significantly different at the $99 \%$ level.

Chirp pulse pattern comparisons and diagnosis. - Visual inspection of song oscillograms revealed that $O$. rohiniae sp. nov. has chirps with grouped pulses. The chirp pulse grouping patterns of $O$. rohiniae sp. nov. are 2-2, 2-3, 2-3-2 or 2-3-3 (Fig. 19). Of the 601 individual chirps examined, $76.9 \%$ were $2-3$ or $2-3-2$ patterns. The predominant patterns for $O$. fultoni were $2-3$ or $2-3-3$. We found

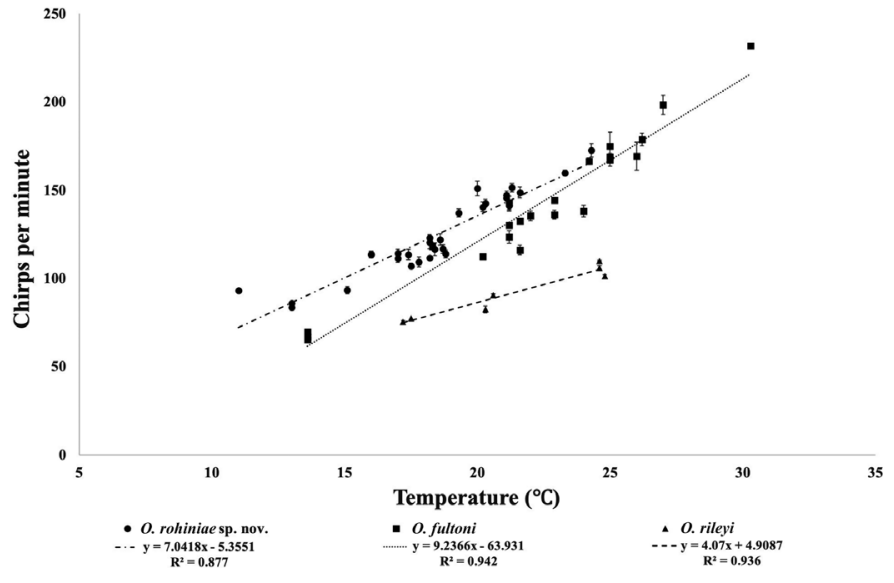

Fig. 17. Change in chirps per minute with temperature of $O$. rohiniae sp. nov., O. fultoni, and O. rileyi. Data for O. fultoni and O. rileyi recordings in Suppl. material 2: source recordings.

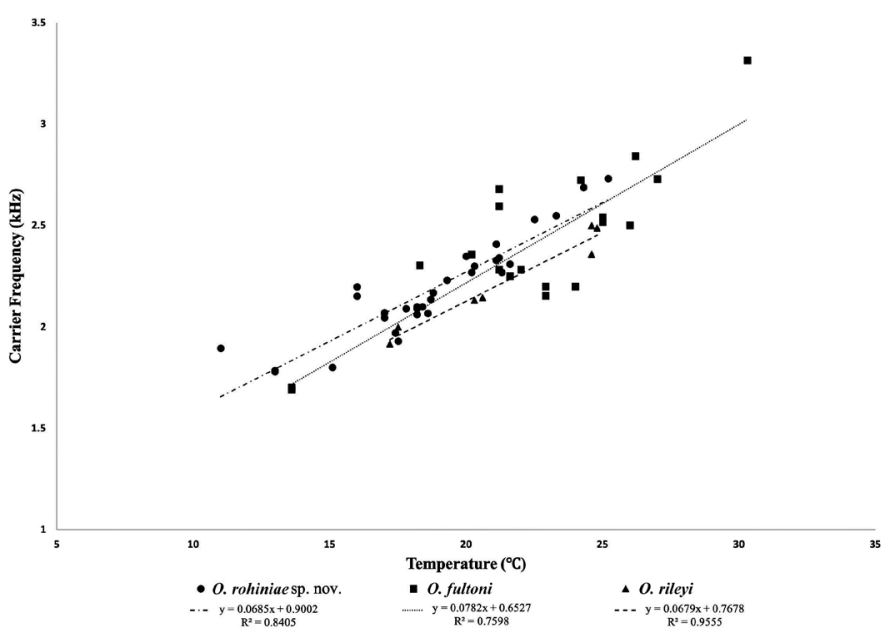

Fig. 18. Change in carrier frequency with temperature of $O$. rohiniae sp. nov., O. fultoni, and O. rileyi. Data for O. fultoni and O. rileyi recordings in Suppl. material 2: source recordings.

$17.0^{\circ} \mathrm{C}$. A. Two chirps; B. Three seconds of chirping. C. 15 seconds of chirping.
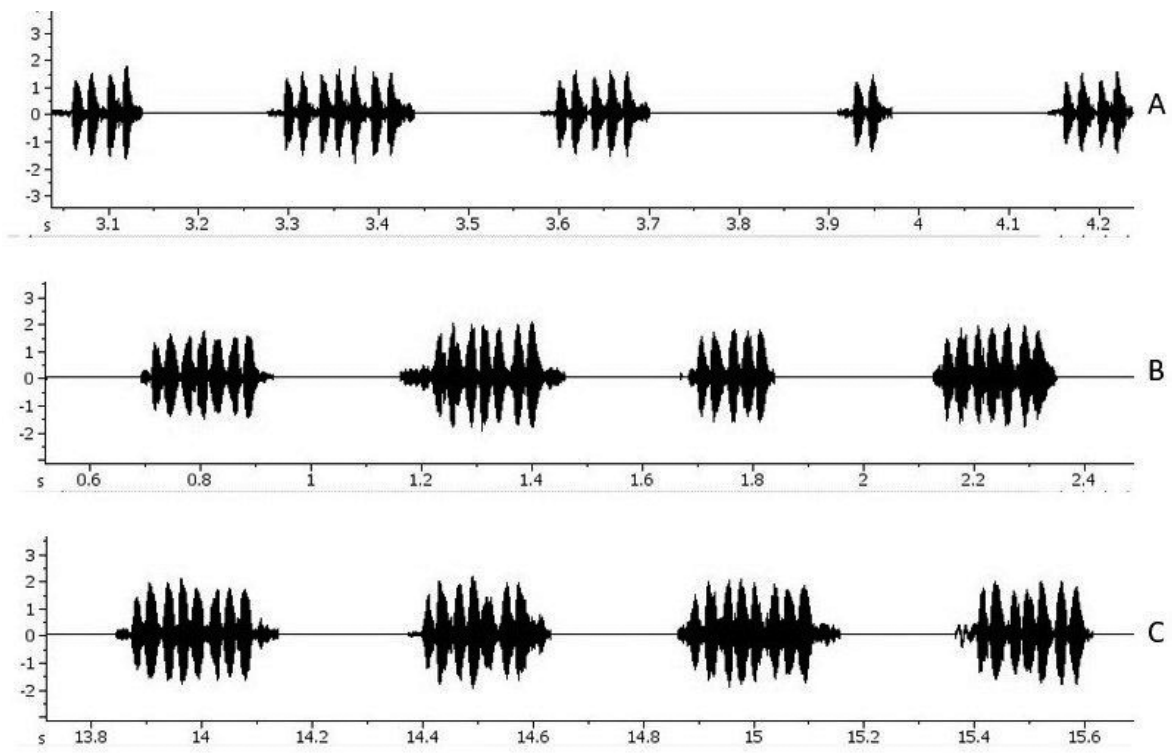

Fig. 19. Pulses per chirp patterns of $O$. rohiniae sp. nov. A. 2-3 or 2-2 pulses pattern; B. 2-3-2 or 2-3 pattern; C. 2-3-3 pattern. 
two instances of apparent aborted chirps with a single 2-pulse grouping, but we found no recordings of a singing $O$. fultoni with a 2-3-2 pattern. Table 1 shows the percentage of occurrence for chirp pulse patterns for O. rohiniae sp. nov., O. fultoni, and O. rileyi. Since $O$. rohiniae sp. nov. has a total of 11 or less pulses per chirp, both $O$. alexanderi and $O$. allardi can be ruled out as their chirps consist of 17-23 or 29-35 pulses, respectively (Walker and Collins 2010). Oecanthus mhatreae does not have grouping of pulses in each chirp (Collins et al. 2019).

Other species comparisons. - The known members of the nigricornis, niveus, and varicornis species groups can be ruled out with nonmatching song types, tegminal widths, antennal markings, or antennal coloring. Other western hemisphere species of Oecanthus can be ruled out for non-matching characters as in Table 2.

Morphological comparisons. - Since both O. rohiniae sp. nov. and $O$. fultoni are members of the rileyi species group, it is not unexpected that no profound differences were evident in the following characters: coloring, antennal markings, metanotal gland, number of stridulatory teeth, tegmen venation, and subgenital plates. The pedicel of $O$. rohiniae sp. nov. has a centered black mark more than one half the size of that on the scape (Fig. 20), which is also found on O. fultoni (Fig. 21) but not on O. rileyi (Fig. 22). These markings can be either round or ovoid. The copulatory blades of $O$. rohiniae sp. nov. have distal hooks that appear somewhat blunted and are positioned at a slight angle (Fig. 23), while those of $O$. fultoni have hooks that are more sharply pointed with tips that reach further midline (Fig. 26). These differences can be compared to drawings in Walker and Gurney (1960) comparing male genitalia of a rileyi species group tree cricket from Tamaulipas, Mexico (Fig. 24) with a snowy tree cricket from Ohio (Fig. 27). While we cannot proclaim that the drawing of the Tamaulipas tree cricket in Fig. 24 is O. rohiniae sp. nov., the differences in the two drawings do affirm that more than one species of the rileyi group exists in Mexico. The difference in the appearance of the hooks on fresh specimens can be seen from a lateral view of the blades, as in Figs 25, 28.

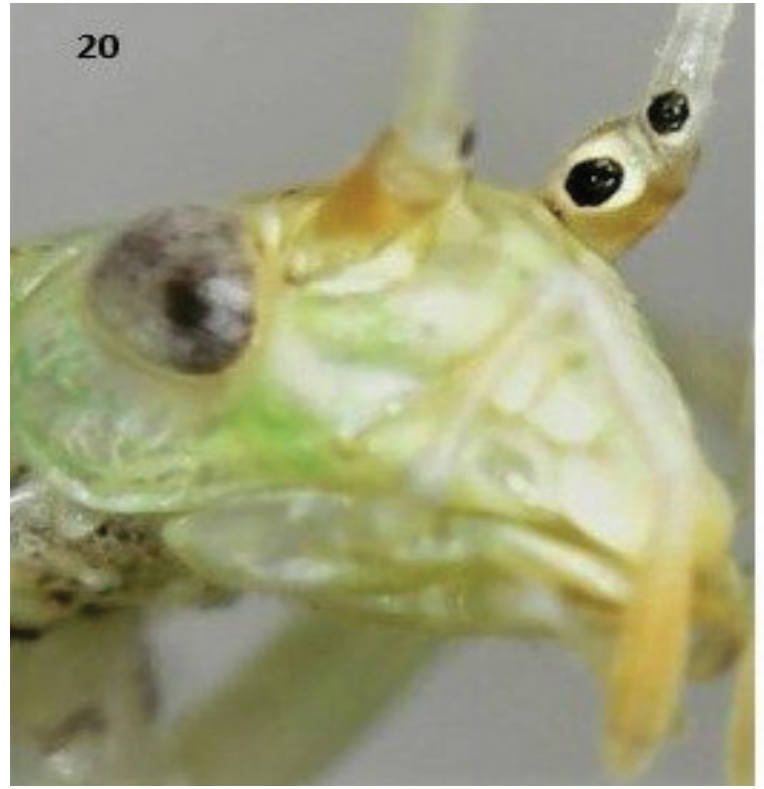

Table 1. Occurrence percentages of grouped pulses per chirp patterns of O. rileyi, O. fultoni, and O. rohiniae sp. nov. ( $\mathrm{n}=$ number of individual chirps sampled).

\begin{tabular}{lcc}
\hline \multicolumn{3}{c}{ Pulse pattern usage percentage } \\
\hline \multicolumn{1}{c}{ Species } & Pattern & Percent \\
\hline O. rileyi & $2-3-3-3$ & 49.5 \\
$\mathrm{n}=198)$ & $2-3-3$ & 40.4 \\
& $2-3-3-3-3$ & 6.1 \\
O. fultoni & $2-3-3$ & 78.4 \\
$(\mathrm{n}=679)$ & $2-3$ & 16.2 \\
& $2-3-3-3$ & 1 \\
& 2 & 0.7 \\
& $3-3$ & 0.15 \\
O. rohiniae sp. nov. & $2-3$ & 41.9 \\
(n=601) & $2-3-2$ & 35 \\
& $2-3-3$ & 16.1 \\
& $2-2$ & 3.9 \\
\hline
\end{tabular}

Table 2. Non-matching characters of western hemisphere Oecanthus species outside the species groups of nigricornis, niveus, rileyi, and varicornis.

\begin{tabular}{lcc}
\hline Oecanthus species & Nonmatching characters & Sources \\
\hline major & Proximal antennal flagellum dark & T. Walker 1967 \\
comma & Comma-shaped mark on pedicel & T. Walker 1967 \\
prolatus & Linear mark on scape & T. Walker 1967 \\
lineolatus & Linear antennal markings & T. Walker 1967 \\
tenuis & Linear antennal markings & T. Walker 1967 \\
valensis & Linear antennal markings & Milach et al. 2016 \\
minutus & No or linear antennal markings & T. Walker 1967 \\
immaculatus & No antennal markings & T. Walker 1967 \\
nanus & No antennal markings & T. Walker 1967 \\
peruvianus & No antennal markings & T. Walker 1967 \\
pictipes & Post-ocular lines & T. Walker 1967 \\
pallidus & Bursts of trilling & Zefa et al. 2012 \\
pictus & Trilling song & Milach et al. 2015 \\
belti & Trilling song & Collins et al. 2014 \\
symesi & Trilling song & Collins et al. 2014 \\
jamaicensis & Trilling song & T. Walker 1969 \\
bakeri & Trilling song & Collins et al. 2014 \\
\hline
\end{tabular}

21
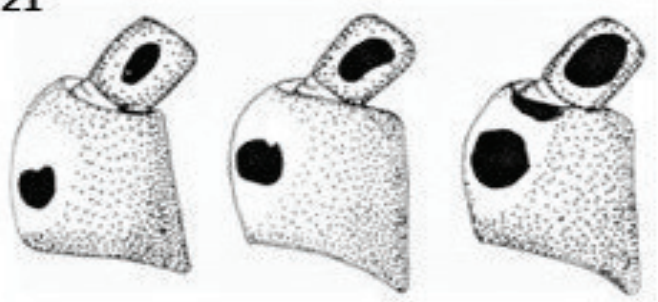

22

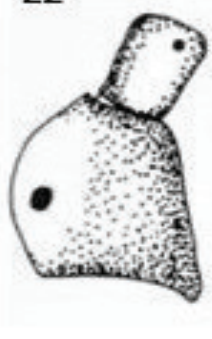

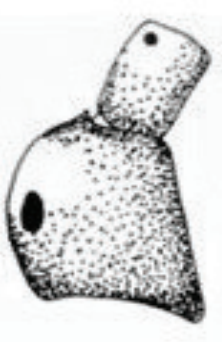

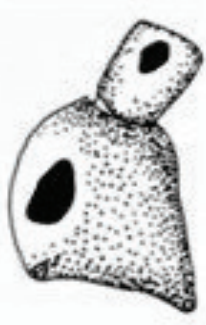

Figs 20-22. Shapes and locations of black markings on pedicel and scape. 20. O. rohiniae sp. nov.; 21. O. fultoni (SINA 2020b); 22. O. rileyi (SINA 2020c). 
23
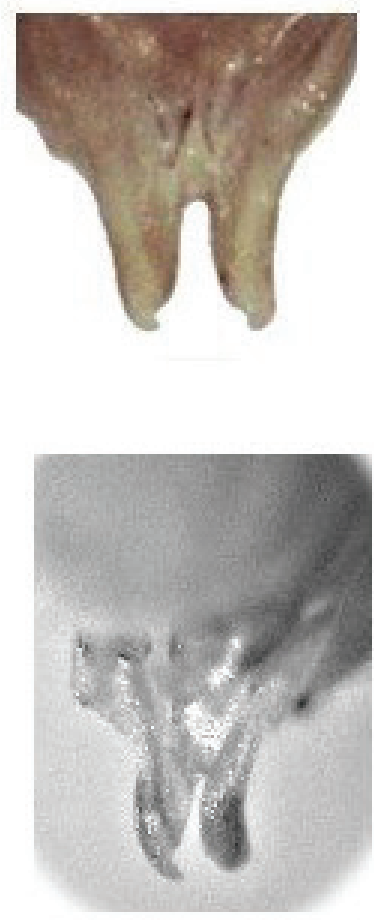

26
24
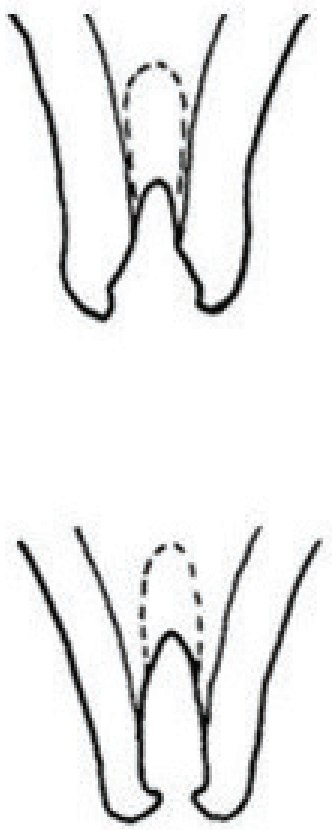

27
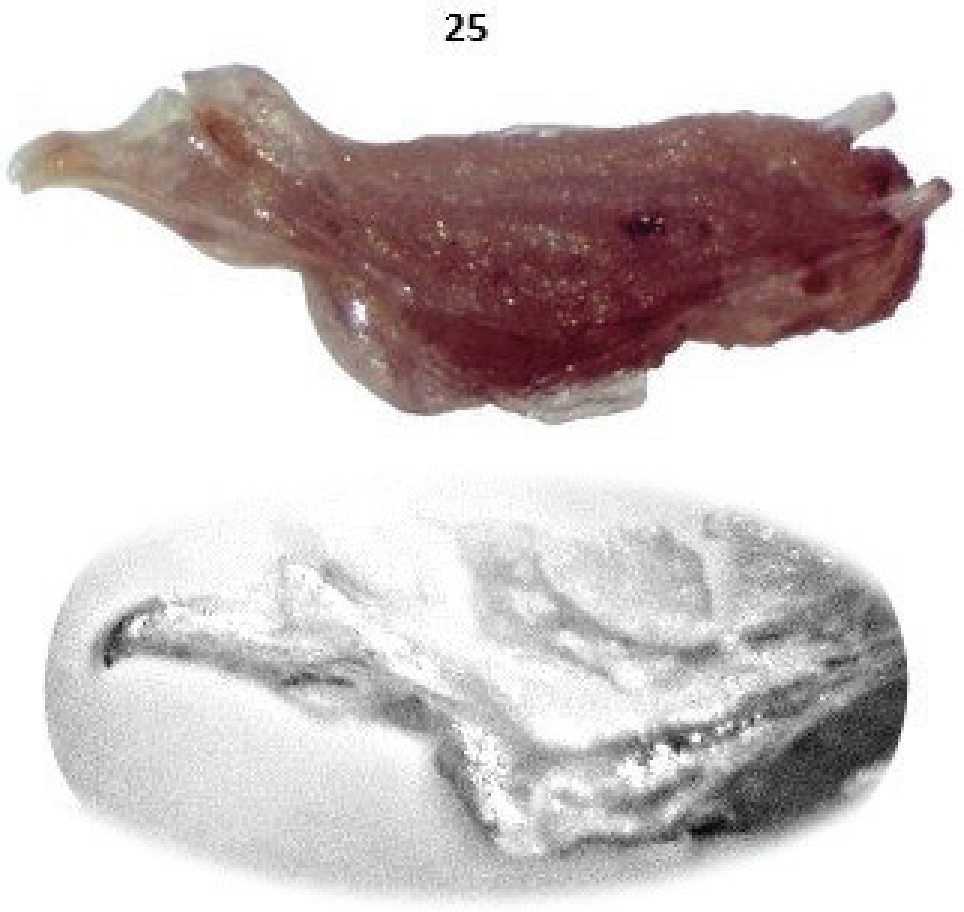

28

Figs 23-28. Copulatory blades of male genitalia. 23. Close up ventral view of O. rohiniae sp. nov.; 24. Drawing of an undetermined rileyi species group tree cricket from Tamaulipas, Mexico (Walker and Gurney 1960); 25. Lateral view of O. rohiniae sp. nov.; 26. Close up ventral view of O. fultoni from Texas, USA; 27. Drawing of O. fultoni from Ohio USA (Walker and Gurney 1960); 28. Lateral view of O. fultoni from Wisconsin, USA.

\section{Discussion}

We described a new species of Oecanthus that falls into the rileyi species group. We were able to rule out other chirping species by the following characters: Size and position of the black mark on the pedicel rules out $O$. rileyi; short chirps (less than nine pulses per chirp) rule out $O$. alexanderi and $O$. allardi; and the grouping of pulses in each chirp rules out $O$. mhatreae.

Oecanthus fultoni is morphologically quite similar to $O$. rohiniae sp. nov., however the distal hooks on the male copulatory blades of $O$. rohiniae sp. nov. have a slightly blunted point, while the hooks of $O$. fultoni are more sharply pointed. Recorded chirps of $O$. fultoni do not include the 2-3-2 pulse pattern as in chirps of $O$. rohiniae sp. nov. T-test analysis of the regression lines for chirps/min rate as it varies with temperature for $O$. rohiniae sp. nov. and $O$. fultoni indicated a significant difference between the two species.

A list of recordings by Alexander, which includes notations of 'fultoni' tree crickets, can be viewed in Suppl. material 1: historical recordings. In 1966, Thomas J. Walker analyzed several of Alexander's recordings. With his permission, we provide a table of these analyses in Suppl. material 5: analyses of historical recordings. These recordings shed light on the need for further investigation of chirping tree crickets in Mexico. Although the Cri-Cri tree cricket is currently only described from Querétaro, there have been other photos from Mexico of similar looking tree crickets submitted to iNaturalist.

\section{Acknowledgements}

We thank the California Academy of Sciences for maintaining the website iNaturalist.org, which allows scientists and the general public from around the world to post photographs and sound recordings of insects. We are grateful to Thomas J. Walker, Professor Emeritus, University of Florida, for the wealth of knowledge he generously shares. We thank Thomas Moore, Professor Emeritus, University of Michigan, Museum of Zoology, for his diligent search for Alexander's tapes. We also thank Ludivina BarrientosLozano, Professor and Researcher of Tecnológio Nacional de México-Instituto Tecnológico de Ciudad Victoria, and Alejandro Zaldivar Riverón, Professor and Researcher, Instituto de Biología, Universidad Nacional Autónoma de México, who offered lab facilities and assistance. Finally, we appreciate valuable suggestions by Tony Robillard, Edison Zefa, Klaus-Gerhard Heller, and an anonymous reviewer for improving this paper. The Orthopterists' Society provided funding for publishing this paper.

\section{References}

Barrientos-Lozano L, Rocha-Sánchez AY (2013) A new species of the genus Pterodichopetala (Orthoptera: Tettigoniidae: Phaneropterinae) from Northeastern Mexico. Journal of Orthoptera Research 22: 3-13. https://doi.org/10.1665/034.022.0102

Calderón de Rzedowski G, Rzedowski J (2001) Flora Fanerogámica del Valle de Mexico ( $2^{\text {nd }}$ edn.), ISBN 970-9000-17-9. http://www1.inecol. edu.mx/publicaciones/FLORA_FANEROGAMIMGCA.htm 
Chopard L (1961) Les divisions du genre Gryllus basees sur l'étude de l'appareil copulateur (Orth. Gryllidae) EOS: Revista española de entomología 37: 267-287. http://hdl.handle.net/10261/157258

Chopard L (1969) The Fauna of India and Adjacent Countries, Orthoptera (Vol. 2). Baptist Mission Press, 421 pp. http://faunaofindia. nic.in/php/fi/fi_books_toc.php?book_id=003andtype=fiandbook_ title $=$ Orthoptera-Grylloidea

Cigliano MM, Braun H, Eades DC, Otte D (2020) Orthoptera Species File, Version 5.0. http://Orthoptera.SpeciesFile.org [Last accessed January 2020]

Collins N, Coronado I, Govaerts B (2019) Oecanthus mhatreae sp. nov. (Orthoptera: Gryllidae: Oecanthinae): a new species of tree cricket from Mexico, with an irregular song pattern and unique chirp-like trill configuration. Journal of Orthoptera Research 28: 137-143. https://doi. org/10.3897/jor.28.33781

Collins N, van den Berghe E, Carson L (2014) Two new species of Neoxabea, three new species of Oecanthus, and documentation of two other species in Nicaragua (Orthoptera: Gryllidae: Oecanthinae). Transactions of the American Entomological Society 140: 163-184. https:// doi.org/10.3157/061.140.0111

Cornell Lab (2020) Macaulay Library/Wilbur Hershberger/Laurel Symes/ Thomas J. Walker. https://search.macaulaylibrary.org/catalog?view=L istandsearchField=animals [Last accessed January 2020]

Desutter L (1987) Structure et évolution du complexe phallique des Gryllidea (Orthoptères) et classification des genres Nétropicaux de Grylloidea. Première Partie. Annales de la Société Entomologique de France 23: 213-239. https://gallica.bnf.fr/ark:/12148/bpt6k6139207n/f3.image

Fulton BB (1915) The tree crickets of New York: life history and bionomics. New York Agricultural Experiment Station. Technical Bulletin 1 42: 3-47. https://orthsoc.org/sina/s576lf15.pdf

iNaturalist.org (2020) iNaturalist. California Academy of Sciences, San Francisco, California. https://www.inaturalist.org/observations/19722394 [Last accessed January 2020]

Martínez y Díaz de Salas M, Hernández Sandoval L, Pantoja Hernández Y, Gómez Sánchez M, Bárcenas Luna R, Cabrera Luna A (2017) Guía Ilustrada de la Flora del Valle de Querétaro. Universidad Autónoma de Querétaro. Primera edición agosto de 2017. http://bioteca.biodiversidad.gob.mx/janium/Documentos/13302.pdf

Milach EM, Martins LP, Costa MKM, Gottschalk MS, Oliveira GL, Redü DR, Neutzling AS, Dornelles JEF, Vasconcellos LA, Zefa E (2015) A new species of tree crickets Oecanthus (Orthoptera, Gryllidae, Oecanthinae) in tobacco plantation from southern Brazil, with body color variation. Zootaxa 4018: 266-278. https://doi.org/10.11646/zootaxa.4018.2.6

Milach DM, Costa MKM, Martins LP, Nunes LA, Silva DSM, Garcia FRM, Oliveira EC, Zefa E (2016) New species of tree cricket Oecanthus Serville, 1831 (Orthoptera: Gryllidae: Oecanthinae) from Reserva Natural Vale, Espírito Santo, Brazil, with chromosome complement. Zootaxa 4173: e138. https://doi.org/10.11646/zootaxa.4173.2.4

NWC (2020) National Water Commission weather. [Last accessed April 2019] https://smn.cna.gob.mx

Rocha-Sánchez AY, Almaguer-Sierra P, Barrientos-Lozano L (2018) Procedimiento básico para la extracción y preparación de genitalia interna en Tettigoniidae (Orthoptera: Ensifera). TecnoINTELECTO 15: 11-18. http://www.itvictoria.edu.mx/personal/tecnointelecto/1-TecnoINTELE-Vol-15(2)-DIC-2018-05-VIII-19.pdf

SINA (2020a) Key to Genera of Tree Crickets. Singing Insects of North America. https://orthsoc.org/sina/s576k.htm [Last accessed January 2020]

SINA (2020b) Key to Species Groups of Oecanthus (common tree crickets). Singing Insects of North America. https://orthsoc.org/sina/g576a. htm [Last accessed January 2020]

SINA (2020c) Riley's tree cricket. Singing Insects of North America. https:// orthsoc.org/sina/588a.htm [Last accessed January 2020]

Walker TJ (1962) The taxonomy and calling songs of United States tree crickets (Orthoptera: Gryllidae: Oecanthinae). I. The genus Neoxabea and the niveus and varicornis groups of the genus Oecanthus. Annals of the Entomological Society of America 55: 303-322. https://doi. org/10.1093/aesa/55.3.303

Walker TJ (1963) The taxonomy and calling songs of United States tree crickets (Orthoptera: Gryllidae: Oecanthinae). II. The nigricornis group of the genus Oecanthus. Annals of the Entomological Society of America 56: 772-789. https://doi.org/10.1093/aesa/56.6.772

Walker TJ (1967) Revision of the Oecanthinae (Orthoptera: Gryllidae) of America South of the United States. Annals of the Entomological Society of America 60: 784-796. https://doi.org/10.1093/aesa/60.4.784

Walker TJ (1969) Oecanthus jamaicensis, n. sp.: A cecropia-inhabiting cricket (Orthoptera: Gryllidae). The Florida Entomologist 52: 263-265. https://doi.org/10.2307/3493879

Walker TJ, Collins N (2010) New world thermometer crickets: the Oecanthus rileyi species group and a new species from North America. Journal of Orthoptera Research 19: 371-371. https://doi. org/10.1665/034.019.0227

Walker TJ, Gurney A (1960) A new species of Oecanthus from the West Indies (Orthoptera, Gryllidae) The Florida Entomologist 43: 9-13. https://doi.org/10.2307/3492515

Wonnacott TH, Wonnacott RJ (1977) Introductory statistics (3 ${ }^{\text {rd }}$ edn.) John Wiley and Sons, Inc, New York, 650 pp. ISBN 0-471-02528-3.

Zefa E, Neutzling AS, Redü DR, Oliveira LG, Martins LP (2012) A new species of Oecanthus and Oecanthus lineolatus Saussure, 1897 from Southern Brazil: species description, including phallic sclerites, metanotal glands and calling song (Orthoptera: Gryllidae: Oecanthinae). Zootaxa 3360: 53-67. https://doi.org/10.11646/zootaxa.3360.1.2

\section{Supplementary material 1}

\section{Author: Thomas Moore}

Data type: Notes of recordings

Explanation note: Notes for recordings made by Richard D. Alexander throughout Mexico in 1965 - with notations for 'fultoni' like tree crickets.

Copyright notice: This dataset is made available under the Open Database License (http:/opendatacommons.org/licenses/ odbl/1.0/). The Open Database License (ODbL) is a license agreement intended to allow users to freely share, modify, and use this Dataset while maintaining this same freedom for others, provided that the original source and author(s) are credited.

Link: https://doi.org/10.3897/jor.30.50039.suppl1

\section{Supplementary material 2}

Author: Wil Hershberger

Data type: Song data

Explanation note: Excel spreadsheet showing source recordings and data from Macaulay Lab for O. fultoni and O. rileyi.

Copyright notice: This dataset is made available under the Open Database License (http://opendatacommons.org/licenses/ odbl/1.0/). The Open Database License (ODbL) is a license agreement intended to allow users to freely share, modify, and use this Dataset while maintaining this same freedom for others, provided that the original source and author(s) are credited.

Link: https://doi.org/10.3897/jor.30.50039.suppl2

\section{Supplementary material 3}

Author: Bruno Govaerts

Data type: WAV file

Explanation note: WAV file with a recording of $O$. rohiniae sp. nov. made in Querétaro, Mexico. Outdoors - Temperature $16.0^{\circ} \mathrm{C}$. Copyright notice: This dataset is made available under the Open Database License (http://opendatacommons.org/licenses/ odbl/1.0/). The Open Database License (ODbL) is a license agreement intended to allow users to freely share, modify, and use this Dataset while maintaining this same freedom for others, provided that the original source and author(s) are credited. Link: https://doi.org/10.3897/jor.30.50039.suppl3 


\section{Supplementary material 4}

Author: Bruno Govaerts

Data type: Video

Explanation note: MPG file with a video of a singing male O. rohiniae sp. nov. taken outdoors in Querétaro, Mexico. A singing O. mhatreae is in the background.

Copyright notice: This dataset is made available under the Open Database License (http://opendatacommons.org/licenses/ odbl/1.0/). The Open Database License (ODbL) is a license agreement intended to allow users to freely share, modify, and use this Dataset while maintaining this same freedom for others, provided that the original source and author(s) are credited.

Link: https://doi.org/10.3897/jor.30.50039.suppl4

\section{Supplementary material 5}

Author: Thomas J. Walker

Data type: Song Analyses

Explanation note: Song analyses by Thomas J Walker in 1966 of Richard D Alexander's 1965 recordings from Mexico, which included 'fultoni' tree crickets.

Copyright notice: This dataset is made available under the Open Database License (http://opendatacommons.org/licenses/ odbl/1.0/). The Open Database License (ODbL) is a license agreement intended to allow users to freely share, modify, and use this Dataset while maintaining this same freedom for others, provided that the original source and author(s) are credited.

Link: https://doi.org/10.3897/jor.30.50039.suppl5 